\title{
Coronaviruses and gastrointestinal diseases
}

\author{
Xi Luo ${ }^{1,2}$, Guan-Zhou Zhou' ${ }^{1}$, Yan Zhang ${ }^{1}$, Li-Hua Peng ${ }^{1}$, Li-Ping Zou² and Yun-Sheng Yang ${ }^{\text {** }}$
}

\begin{abstract}
The effects of coronaviruses on the respiratory system are of great concern, but their effects on the digestive system receive much less attention. Coronaviruses that infect mammals have shown gastrointestinal pathogenicity and caused symptoms such as diarrhea and vomiting. Available data have shown that human coronaviruses, including the newly emerged SARS-CoV-2, mainly infect the respiratory system and cause symptoms such as cough and fever, while they may generate gastrointestinal symptoms. However, there is little about the relation between coronavirus and digestive system. This review specifically addresses the effects of mammalian and human coronaviruses, including SARS-CoV-2, on the digestive tract, helping to cope with the new virus infection-induced disease, COVID-19.
\end{abstract}

Keywords: Mammal coronaviruses, Human coronaviruses, Digestive system, Coronavirus disease 2019 (COVID-19)

\section{Background}

The coronavirus disease 2019 (COVID-19) pandemic caused by severe acute respiratory syndrome coronavirus 2 (SARS-CoV-2) has resulted in severe adverse impacts worldwide. Available data have shown that patients with COVID-2019 present respiratory symptoms and fever; however, approximately $8.8-60.6 \%$ of patients suffer from gastrointestinal symptoms, such as decreased appetite, nausea, vomiting, and diarrhea, as well as possible abnormal liver function [1-3]. Although the impacts of SARS-CoV-2 on the gastrointestinal (GI) tract remain unclear, studies of other coronaviruses have revealed a close relation to GI symptoms. We reviewed the coronaviruses that cause GI disorders in mammals or humans to facilitate coping with SARS-CoV-2 infection.

Coronaviruses $(\mathrm{CoV})$ are enveloped, single-stranded, positive-sense RNA viruses that belong to the order Nidovirales. They contain the most abundant RNA genome, with lengths from 27 to $32 \mathrm{~kb}$ among all known viruses, and are members of the family Coronaviridae, subfamily Coronavirinae. This subfamily consists of four genera, Alphacoronavirus, Betacoronavirus, Gammacoronavirus

\footnotetext{
*Correspondence: sunnyddc@plagh.org

'Department of Gastroenterology and Hepatology, the First Medical Center, Chinese PLA General Hospital, Beijing 100853, China

Full list of author information is available at the end of the article
}

and Deltacoronavirus $(\alpha-, \beta-, \gamma-$ and $\delta-\mathrm{CoV})$. Specifically, $\alpha$ - and $\beta$ - coronaviruses mainly infect the human respiratory system, mammalian intestine, and central nervous system; $\gamma$ - and $\delta$ - coronaviruses primarily infect birds (or poultry). The coronaviruses infecting humans can cause severe diseases. To date, seven coronaviruses ( $\mathrm{HCoVs}$ ) have been reported in humans, namely, human coronavirus 229E (HCoV-229E), human coronavirus NL63 (HCoV-NL63), human coronavirus HKU1 (HCoVHKU1), human coronavirus OC43 (HCoV-OC43), Middle East respiratory syndrome coronavirus (MERS-CoV), severe acute respiratory syndrome coronavirus (SARS-CoV), and the recently identified SARS-CoV-2 $[4,5]$.

\section{Enteric coronavirus in mammals}

Porcine coronaviruses, such as porcine transmissible gastroenteritis virus (TGEV), porcine epidemic diarrhea virus (PEDV), and swine acute diarrhea syndrome coronavirus (SADS-CoV), are classified as genus Alphacoronavirus, while porcine deltacoronavirus (PDCoV) belongs to genus Deltacoronavirus. These porcine coronaviruses can infect piglets of all ages by invading the GI tract, with clinical signs of diarrhea, vomiting, and anorexia, resulting in dehydration, metabolic acidosis, and hyperkalemia and eventually leading to death. Scattered intestinal epithelial cell necrosis and villus damage are 
the primary pathological manifestations of porcine coronavirus infection [6-8]. There is a higher incidence of porcine coronavirus infection during winter and spring; piglets are particularly more susceptible than adult pigs to porcine coronavirus, with a higher mortality rate [6]. In addition, mixed infection of these four porcine coronaviruses is common among infected pig herds. Current evidence indicates that porcine coronaviruses can be transmitted through the fecal-oral route and infect small intestinal epithelial cells due to resistance to low $\mathrm{pH}$ and proteolytic enzymes, causing osmotic diarrhea in infected pigs and even death [9]. In addition to fecal-oral transmission, PDCoV can also be transmitted through the respiratory tract and induce pneumonia [10]. Etiological treatment with additional nutrient supply should be followed to lower mortality, which is caused by secondary infection and dehydration due to diarrhea. It is essential to maintain water and electrolyte balance [9]. In addition, probiotics, such as Lactobacillus, are reported to be effective in treating porcine coronavirus diarrhea [11].

Canine coronaviruses (CCoV) involve two serotypes, $\mathrm{CCoV}$-I and CCoV-II, which belong to $\alpha$-coronavirus. $\mathrm{CCoV}$-II can be further divided into CCoV-IIa (the classical biotypes and pantropic biotypes) and CCoV-IIb. Classical CCoV-IIa is restricted to the small intestine, causing symptoms such as decreased appetite, vomiting, watery diarrhea, and dehydration. Pantropic CCoV-IIa causes subacute bronchial pneumonia and leukopenia (mainly $\mathrm{CD}^{+}{ }^{+} \mathrm{T}$ cells), as well as hemorrhage and necrosis in multiple organs (e.g., kidney and liver) $[12,13]$. Canine coronavirus disease generally has a high incidence rate, has a low mortality rate, and presents mild gastrointestinal symptoms. Severe cases are often accompanied by coinfection with other viruses. Prevention and treatment of canine coronavirus disease include strengthening hygiene, quarantine, and maintaining water and electrolyte balance. Specific antiviral therapies, such as vaccines and monoclonal antibodies, are also used [12].

Feline coronavirus (FCoV) includes feline enteric coronavirus (FECV) and feline infectious peritonitis virus (FIPV), both of which are $\alpha$-coronaviruses. FECV usually causes mild intestinal symptoms in cats but self-limiting recovery due to weak toxicity. In contrast, the toxicity of FIPV is generally strong and leads to a high fatality rate, causing systemic inflammatory diseases are known as feline infectious peritonitis (FIP). Generally, FCoV replicates in host intestinal epithelial cells and is excreted with feces [14, 15]. At the early stage of FIP, hosts present mild symptoms of GI infection. Later, hydrothorax and ascites will appear, mesenteric lymph nodes will be enlarged, and multiple organs in the body will be involved [16]. It is worth mentioning that some cats present oral lesions, such as gingivitis and mucosal ulcers, and halitosis as the most obvious symptoms, which might be strong evidence for the existence of virus infection [17]. The recommended treatment includes antiviral agents, secondary infection prevention, osmotic pressure increase, and fluid infusion. In addition, glucocorticoids are the main immunosuppressive agents in the treatment of FIP [16].

Bovine coronavirus $(\mathrm{BCoV})$ is a member of the genus $\beta$-coronavirus, which has high similarity with human coronavirus $\mathrm{OC} 43$ in antigenicity and gene sequence [18]. $\mathrm{BCoV}$ can be transmitted through the respiratory and digestive tracts and damages small intestinal epithelial cells or respiratory epithelial cells, causing diarrhea, intestinal bleeding, fever, and sometimes cough and runny nose. BCoV RNA could be detected in the stool of both healthy and diarrheal cattle, and the detection rate was higher in stool samples from diarrheal cattle [19]. Currently, there is no specific treatment, and symptomatic relief is the primary therapy. In addition, liquid supplementation is essential in severe conditions. Some studies have suggested that Lactobacillus preparations are effective in treating bovine diarrhea, but this assertion is still controversial [20].

\section{Coronavirus in the human gastrointestinal tract}

The $\alpha$-coronaviruses HCoV-229E and HCoV-NL63 were isolated in 1965 and 2004, respectively [21, 22]. Epidemiological investigation shows that humans are generally susceptible to these two viruses, and nearly all children have been infected with $\mathrm{HCoV}-229 \mathrm{E}$ and HCoV-NL63 at an early stage [23]. HCoV-229E mainly causes mild respiratory symptoms, including headache, runny nose, sore throat, fever, and cough [24, 25]. HCoV-NL63 infects the lower respiratory tract and causes bronchiolitis, pneumonia, etc. [26].

Both $\mathrm{HCoV}-\mathrm{OC} 43$ and $\mathrm{HCoV}-\mathrm{HKU} 1$ belong to lineage A of the genus $\beta$-coronavirus, which were found in 1967 and 2005, respectively $[27,28]$. Although the source of $\mathrm{HCoV}-\mathrm{OC} 43$ remains uncertain, studies have suggested that HCoV-OC43 is closely related to lineage A of the genus $\beta$-coronavirus, especially bovine coronavirus (BCoV) [18]. HCoV-OC43 typically causes mild respiratory symptoms but infects and leads to severe lower respiratory tract infection in some immunocompromised cases [29]. In addition to upper respiratory tract infection, $\mathrm{HCoV}-\mathrm{HKU} 1$ can also causes lower respiratory tract infections, such as pneumonia and bronchitis [29], with occasional reported fatal cases. It is rarely reported that the above four human coronaviruses cause digestive disorders [30]. However, approximately $25-38 \%$ of patients infected with these four human coronaviruses develop gastrointestinal symptoms [31]. 


\section{SARS-COV}

SARS-CoV was isolated and identified in 2003, belonging to lineage $\mathrm{B}$ of the genus $\beta$-coronavirus. Fever and respiratory symptoms are the most common signs of the infection, and additional GI symptoms also appear as anorexia, nausea, vomiting, abdominal pain, and diarrhea. A retrospective study investigated 752 people with SARS-CoV infection and indicated that approximately $20 \%$ of patients had diarrhea in their initial stages [32]. Another investigation showed that 55 of 75 patients with SARS-CoV infection presented watery stools approximately 1 week after onset [33]. Altogether, approximately 20-25\% of SARS patients will have diarrhea [2].

The majority of SARS-CoV enters human cells through angiotensin-converting enzyme 2 (ACE2), which is expressed on lung and gastrointestinal cells [34]. Currently, reverse transcription-polymerase chain reaction (RT-PCR) tests are the primary methods of pathogenic detection by using upper respiratory tract specimens via throat swabs, lower respiratory tract specimens such as bronchoalveolar lavage fluid, and blood, urine, or fecal specimens. SARS-CoV is persistently positive with intestinal specimen tests for the longest duration, from day 5 after the onset of illness to over 30 days, with the peak at day 11 in some patients [35]. In an investigation of 67 patients who were diagnosed with SARS through stool RNA tests, 65 patients (97\%) were positive at day 14 after the onset of illness [35]. In another cohort study of 75 patients with SARS, nasopharyngeal aspirates from 51 patients showed positive results on day 14 with a nucleic acid test. Subsequently, 15 patients were followed up to day 21, and stool samples from 10 of them (67\%) remained positive [33]. This result suggests that the release of the virus via the fecal system occurs for a longer period of time than that by the airways. As a result, detection from different sample types is necessary, and the timeliness of detection is not the same. In addition, patients with gastrointestinal symptoms should have a longer isolation period. Comprehensive judgment is needed during practice.

\section{MERS-COV}

MERS-CoV was first detected in Saudi Arabia in September 2012, which belongs to lineage C of Betacoronavirus and binds to the dipeptidyl peptidase 4 (DPP4) receptor [36]. Based on existing evidence, patients with MERS-CoV infection present with fever; respiratory symptoms, including cough, sputum, and dyspnea; and gastrointestinal symptoms, such as anorexia, nausea, vomiting, abdominal pain, and diarrhea, and general shock or kidney damage may also appear during the illness [36]. In a retrospective investigation of 12 patients with severe SARS, 11 patients had shock symptoms, and 7 had acute kidney injury [36]. Another study reported the symptoms of 47 patients with MERS: 12 (26\%) had diarrhea, 10 (21\%) had vomiting, and 8 (17\%) had abdominal pain [37]. Approximately $25 \%$ of patients with MERS have developed diarrhea or abdominal pain at the time of consultation. Some patients initially present with fever and gastrointestinal symptoms, followed by more severe respiratory symptoms [37]. Based on RNA tests, approximately $14.6 \%$ of stool samples from patients with MERS showed positive results [38].

\section{SARS-CoV-2}

SARS-CoV-2 belonging to Betacoronavirus was first reported in 2019 in China, which has significant genetic characteristics distinguished from those of SARS-CoV and MERS-CoV. The genome sequence of SARS-CoV-2 shares over $85 \%$ homology with that of bat SARS-CoVlike viruses (bat-SL-CoVZC45) [39]. The infectious disease (COVID-19) caused by SARS-CoV-2 has similar clinical signs as SARS-CoV infection, including fever and respiratory symptoms, such as cough, sputum, shortness of breath, and breathing difficulties. Furthermore, COVID-19 patients present various digestive symptoms. However, reports on the incidence of gastrointestinal symptoms in COVID-19 patients vary widely. COVID-19-associated diarrhea occurrence has been reported at 3.0\% [40], 7.3\% [1], 10.1\% [1], 2.0\% [41], and $49.5 \%$ [42] in different studies. A study from a single center in Wuhan on 305 patients reported approximately $22.2 \%$ [42]. In a large sample study of 1099 patients across China, the incidence of gastrointestinal symptoms was $3.8 \%$ for patients with diarrhea symptoms [2]. This discrepancy may be attributed to the different sample amounts of each study and the awareness of some mild gastrointestinal symptoms. In some cases, patients even presented with gastrointestinal symptoms alone at the early stage of onset, including anorexia, nausea, vomiting, and diarrhea [41]. Thus, we should pay additional attention to mild GI symptom patients, and COVID-19 screening is strongly recommended for patients with GI symptoms in the epidemic region. The related gastrointestinal symptoms of SARS-CoV-2 may be associated with its receptor. The binding receptor in the human body for SARS-CoV-2 is ACE2, which is highly expressed in type II alveolar epithelial cells and esophageal epithelial cells, and high expression was also found in the ileum and colon [43]. The positive results of gastrointestinal tract samples provide evidence for enteric transmission. Elsewhere, the RNA test for the stool sample of the first COVID-19 patient in the United States showed positive results on day 7 after onset, suggesting the possibility of SARS-CoV-2 transmission in the digestive tract [44]. A similar possibility was found in a study of sixty-two COVID-19 patients in China. There were two mild COVID-19 patients and two severe 
Table 1 Comparison of human and mammalian coronaviruses

\begin{tabular}{|c|c|c|c|c|c|}
\hline Name & Taxonomy & Host & $\begin{array}{l}\text { Gastrointestinal } \\
\text { symptoms }\end{array}$ & Other system symptoms & Ref. \\
\hline$\overline{\mathrm{HCoV}-229 \mathrm{E}}$ & $a$ & $\begin{array}{l}\text { Human/ } \\
\text { bat }\end{array}$ & $\begin{array}{l}\text { Rarely mild } \\
\text { nausea, vomiting, } \\
\text { diarrhea }\end{array}$ & $\begin{array}{l}\text { Common cold symptoms, such as headache, tiredness, } \\
\text { rhinorrhea, sore throat, fever and cough }\end{array}$ & {$[21,24,25]$} \\
\hline HCoV-OC43 & $\beta$-coronavirus lineage $A$ & $\begin{array}{l}\text { Human/ } \\
\text { rat, cow }\end{array}$ & $\begin{array}{l}\text { Rarely mild } \\
\text { nausea, vomiting, } \\
\text { diarrhea }\end{array}$ & $\begin{array}{l}\text { Common cold symptoms, such as headache, tiredness, } \\
\text { rhinorrhea, sore throat, fever and cough }\end{array}$ & {$[27,29]$} \\
\hline SARS-COV & $\beta$-coronavirus lineage $B$ & $\begin{array}{l}\text { Human/ } \\
\text { bat, } \\
\text { masked } \\
\text { civet }\end{array}$ & $\begin{array}{l}\text { Abdominal pain, } \\
\text { nausea, vomiting, } \\
\text { diarrhea }\end{array}$ & $\begin{array}{l}\text { Fever, muscle weakness, tiredness, headache, chill, dyspnea, } \\
\text { pneumonia, multiple organ dysfunction }\end{array}$ & [32-35] \\
\hline HCoV-NL63 & $a$ & $\begin{array}{l}\text { Human/ } \\
\text { bat }\end{array}$ & $\begin{array}{l}\text { Rarely mild } \\
\text { nausea, vomiting, } \\
\text { diarrhea }\end{array}$ & $\begin{array}{l}\text { Common cold symptoms, such as headache, tiredness, } \\
\text { rhinorrhea, sore throat, fever and cough }\end{array}$ & {$[22,26]$} \\
\hline HCoV-HKU1 & $\beta$-coronavirus lineage $A$ & Human & $\begin{array}{l}\text { Rarely mild } \\
\text { nausea, vomiting, } \\
\text { diarrhea }\end{array}$ & $\begin{array}{l}\text { Common cold symptoms, such as headache, tiredness, } \\
\text { rhinorrhea, sore throat, fever and cough }\end{array}$ & {$[28]$} \\
\hline MERS-COV & $\beta$-coronavirus lineage $C$ & $\begin{array}{l}\text { Human/ } \\
\text { bat, camel }\end{array}$ & $\begin{array}{l}\text { Abdominal pain, } \\
\text { nausea, vomiting, } \\
\text { diarrhea }\end{array}$ & $\begin{array}{l}\text { Fever, muscle weakness, tiredness, headache, chill, dyspnea, } \\
\text { pneumonia, multiple organ dysfunction }\end{array}$ & {$[36-38]$} \\
\hline SARS-CoV-2 & $\beta$-coronavirus lineage $B$ & Human & $\begin{array}{l}\text { Abdominal pain, } \\
\text { nausea, vomiting, } \\
\text { diarrhea }\end{array}$ & $\begin{array}{l}\text { Fever, muscle weakness, tiredness, headache, chill, dyspnea, } \\
\text { pneumonia, multiple organ dysfunction }\end{array}$ & {$[1-3,39-45]$} \\
\hline PEDV & a & Porcine & Diarrhea, vomiting & - & {$[6-8]$} \\
\hline TGEV & $a$ & Porcine & Diarrhea, vomiting & - & {$[6-8]$} \\
\hline SADS-CoV & $a$ & $\begin{array}{l}\text { Porcine/ } \\
\text { bat }\end{array}$ & $\begin{array}{l}\text { Acute severe } \\
\text { diarrhea, vomiting }\end{array}$ & Tiredness, rapid weight loss & {$[6-8]$} \\
\hline PDCoV & $\delta$ & Porcine & Diarrhea, vomiting & - & {$[9-11]$} \\
\hline FIPV & $a$ & Feline & Diarrhea, vomiting & $\begin{array}{l}\text { Anorexia, weight loss, dehydration, consecutive fever in the } \\
\text { early stage; } \\
\text { pleural effusion, ascites, enlarged mesenteric lymph nodes, } \\
\text { multiple organ dysfunction, such as in the eyes, kidneys, liver or } \\
\text { central nervous system, in the later stage }\end{array}$ & {$[15,16]$} \\
\hline FECV & a & Feline & $\begin{array}{l}\text { Mild intestinal } \\
\text { infection, diarrhea, } \\
\text { vomiting }\end{array}$ & - & {$[15,16]$} \\
\hline CCoV & $a$ & Canine & $\begin{array}{l}\text { Diarrhea, } \\
\text { sometimes } \\
\text { vomiting }\end{array}$ & - & {$[12,13]$} \\
\hline $\mathrm{BCoV}$ & $\beta$ & Bovine & $\begin{array}{l}\text { Diarrhea, } \\
\text { sometimes } \\
\text { hematochezia }\end{array}$ & $\begin{array}{l}\text { Fever, milk production reduction, anorexia, sometimes cough } \\
\text { and rhinorrhea }\end{array}$ & [18-20] \\
\hline
\end{tabular}

SARS-CoV. Severe acute respiratory syndrome coronavirus; MERS-CoV. Middle East respiratory syndrome coronavirus; PEDV. Porcine epidemic diarrhea virus; TGEV. Transmissible gastroenteritis virus; SADS-CoV. Swine acute diarrhea syndrome coronavirus; PDCoV. Porcine delta coronavirus; FIPV. Feline infectious peritonitis virus; FECV. Feline enteric coronavirus; CCoV. Canine coronavirus; BCoV. Bovine coronavirus

COVID-19 patients (6.5\%) that showed positive results of the fecal RNA test, and only one of the four patients had diarrhea symptoms [2]. In another report, anal swabs from four patients were positive for RNA tests, of which two patients were positive for RNA tests for the esophagus, stomach, duodenum, and rectal mucosa samples [2]. These results indicate that SARS-CoV-2 has potential gastrointestinal transmission. In terms of pathological analysis, one autopsy report of a COVID-19 patient showed segmental dilatation and stenosis of the small intestine [45]. Although autopsy and puncture tissue pathological samples are limited, pathological observations have shown that the mucosal epithelium of the esophagus, stomach, and intestine are degenerated, necrotic, and shed [45]. These studies suggest the possibility of SARS-CoV-2 directly affecting the intestinal mucosa and causing intestinal damage. Similar to the case for SARS-CoV, the detection results of different body part samples are not the same. It was reported that three patients with SARS-CoV-2 had a negative nucleic acid test on throat swab samples after treatment. However, their fecal nucleic acid test results were still 
positive [46], suggesting that in specimens from different sites, the nucleic acid conversion time is not synchronized and that the fecal nucleic acid positive duration may be longer. It tells us that there are some characteristics deserving attention in the diagnosis and quarantine of COVID-19 patients with gastrointestinal symptoms.

\section{Conclusions}

This review describes eight coronaviruses that can infect mammals and cause gastrointestinal symptoms and seven human coronaviruses (see Table 1 for details). Coronaviruses that infect mammals have definite intestinal pathogenicity and can cause related clinical manifestations, such as vomiting and diarrhea, in animals, with high lethality. In addition, some coronaviruses in mammals can be transmitted through digestive and respiratory contaminants. The treatments of mammalian disease mainly comprise symptomatic therapy, fluid supplementation and internal environment maintenance, and probiotics are also useful. Gastrointestinal symptoms, receptor binding, positive nucleic acid results and pathological evidence strongly reveal the strong relationship between SARS-CoV-2 and the gastrointestinal tract. The pathogenesis of the digestive disorders induced by coronaviruses needs to be investigated and revealed.

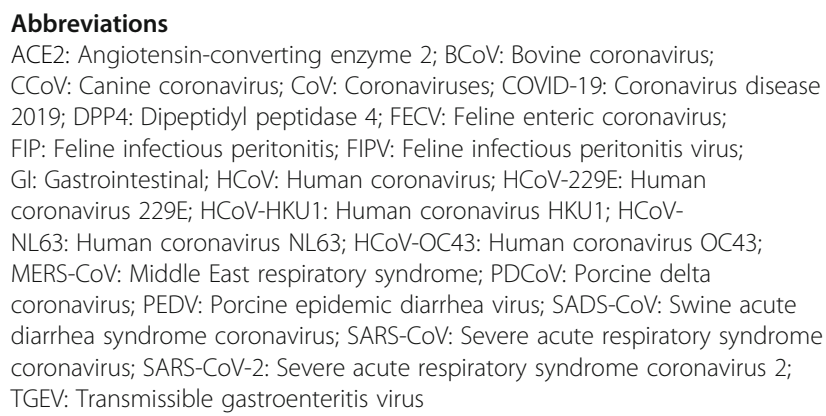

\section{Abbreviations}

ACE2: Angiotensin-converting enzyme 2; BCoV: Bovine coronavirus: CCoV: Canine coronavirus; CoV: Coronaviruses; COVID-19: Coronavirus disease 2019; DPP4: Dipeptidyl peptidase 4; FECV: Feline enteric coronavirus; FIP: Feline infectious peritonitis; FIPV: Feline infectious peritonitis virus; Gl: Gastrointestinal; HCoV: Human coronavirus; HCoV-229E: Human coronavirus 229E; HCoV-HKU1: Human coronavirus HKU1; HCoVNL63: Human coronavirus NL63; HCoV-OC43: Human coronavirus OC43; MERS-CoV: Middle East respiratory syndrome; PDCoV: Porcine delta coronavirus; PEDV: Porcine epidemic diarrhea virus; SADS-CoV: Swine acute diarrhea syndrome coronavirus; SARS-CoV: Severe acute respiratory syndrome coronavirus; SARS-CoV-2: Severe acute respiratory syndrome coronavirus 2; TGEV: Transmissible gastroenteritis virus

\section{Acknowledgements}

Not applicable.

\section{Authors' contributions}

YYS conceived this review; $L X, Z G Z, Z Y$, and YYS performed the review and wrote the paper; PLH and ZLP helped with the review and writing of the paper. The authors read and approved the final manuscript.

\section{Funding}

Not applicable.

\section{Availability of data and materials}

The data and materials used during the current review are all available in this review.

Ethics approval and consent to participate

Not applicable.

\section{Consent for publication}

Not applicable.

\section{Competing interests}

The funder had no role in the study design, data collection, and analysis, decision to publish, or preparation of the manuscript. The authors declare that there are no conflicts of interest in this study.

\section{Author details}

'Department of Gastroenterology and Hepatology, the First Medical Center, Chinese PLA General Hospital, Beijing 100853, China. ${ }^{2}$ Department of Pediatrics, the First Medical Center, Chinese PLA General Hospital, Beijing 100853, China.

Received: 10 June 2020 Accepted: 2 October 2020

Published online: 14 October 2020

\section{References}

1. Wang D, Hu B, Hu C, Zhu F, Liu X, Zhang J, et al. Clinical characteristics of 138 hospitalized patients with 2019 novel coronavirus-infected pneumonia in Wuhan, China. JAMA. 2020;323(11):1061-9.

2. Guan WJ, Ni ZY, Hu Y, Liang WH, Ou CQ, He JX, et al. Clinical characteristics of coronavirus disease 2019 in China. N Engl J Med. 2020;382(18):1708-20.

3. Nobel YR, Phipps M, Zucker J, Lebwohl B, Wang TC, Sobieszczyk ME, et al. Gastrointestinal symptoms and coronavirus disease 2019: a case-control study from the United States. Gastroenterology. 2020;159(1):373-5.

4. Mclntosh K, Peiris JSM. Coronaviruses. In: Clinical virology. 3rd ed. Washington DC: ASM Press; 2009.

5. International Committee on Taxonomy of Viruses. https://talk.ictvonline.org/ taxonomy. (Accessed on 1 Sep 2020).

6. Zhou P, Fan H, Lan T, Yang XL, Shi WF, Zhang W, et al. Fatal swine acute diarrhoea syndrome caused by an HKU2-related coronavirus of bat origin. Nature. 2018;556(7700):255-8.

7. Jung K, Wang Q, Scheuer KA, Lu Z, Zhang Y, Saif LJ. Pathology of US porcine epidemic diarrhea virus strain PC21A in gnotobiotic pigs. Emerg Infect Dis. 2014;20(4):662-5.

8. Madson DM, Magstadt DR, Arruda PH, Hoang H, Sun D, Bower LP, et al. Pathogenesis of porcine epidemic diarrhea virus isolate (US/lowa/18984/ 2013) in 3-week-old weaned pigs. Vet Microbiol. 2014;174(1-2):60-8.

9. Niederwerder MC, Hesse RA. Swine enteric coronavirus disease: a review of 4 years with porcine epidemic diarrhoea virus and porcine deltacoronavirus in the United States and Canada. Transbound Emerg Dis. 2018:65(3):660-75.

10. Boley PA, Alhamo MA, Lossie G, Yadav K, Vasquez-Lee M, Saif LJ, et al. Porcine deltacoronavirus infection and transmission in poultry, United States. Emerg Infect Dis. 2020;26(2):255-65.

11. Kumar R, Seo BJ, Mun MR, Kim CJ, Lee I, Kim H, et al. Putative probiotic lactobacillus spp. from porcine gastrointestinal tract inhibit transmissible gastroenteritis coronavirus and enteric bacterial pathogens. Tropl Anim Health Prod. 2010;42(8):1855-60.

12. Licitra BN, Duhamel GE, Whittaker GR. Canine enteric coronaviruses: emerging viral pathogens with distinct recombinant spike proteins. Viruses. 2014;6(8):3363-76

13. Decaro N, Buonavoglia C. Canine coronavirus: not only an enteric pathogen Vet Clin North Am Small Anim Pract. 2011;41(6):1121-32.

14. Pedersen NC. A review of feline infectious peritonitis virus infection: 19632008. J Feline Med Surg. 2009;11(4):225-58.

15. Porter E, Tasker S, Day MJ, Harley R, Kipar A, Siddell SG, et al. Amino acid changes in the spike protein of feline coronavirus correlate with systemic spread of virus from the intestine and not with feline infectious peritonitis. Vet Res. 2014:45(1):49.

16. Addie D, Belák S, Boucraut-Baralon C, Egberink H, Frymus T, Gruffydd-Jones $T$, et al. Feline infectious peritonitis. $A B C D$ guidelines on prevention and management. J Feline Med Surg. 2009;11(7):594-604.

17. Dokuzeylul B, Kayar A, Or ME. Prevalence of systemic disorders in cats with oral lesions. Vet Med. 2016;63:219-23.

18. Zhang XM, Herbst W, Kousoulas KG, Storz J. Biological and genetic characterization of a hemagglutinating coronavirus isolated from a diarrhoeic child. J Med Virol. 1994;44(2):152-61.

19. Gomez DE, Arroyo LG, Poljak Z, Viel L, Weese JS. Detection of bovine coronavirus in healthy and diarrheic dairy calves. J Vet Intern Med. 2017; 31(6):1884-91

20. Kim Pl, Jung MY, Chang YH, Kim S, Kim SJ, Park YH. Probiotic properties of Lactobacillus and Bifidobacterium strains isolated from porcine gastrointestinal tract. Appl Microbiol Biotechnol. 2007;74(5):1103-11. 
21. Hamre D, Procknow JJ. A new virus isolated from the human respiratory tract. Proc Soc Exp Biol Med. 1966;121(1):190-3.

22. Fouchier RA, Hartwig NG, Bestebroer TM, Niemeyer B, de Jong JC, Simon JH, et al. A previously undescribed coronavirus associated with respiratory disease in humans. Proc Natl Acad Sci U S A. 2004;101(16):6212-6.

23. Dijkman R, Jebbink MF, El Idrissi NB, Pyrc K, Müller MA, Kuijpers TW, et al. Human coronavirus NL63 and 229E seroconversion in children. J Clin Microbiol. 2008;46(7):2368-73.

24. Hendley JO, Fishburne HB, Gwaltney JM Jr. Coronavirus infection in working adults. Eight-year study with 229 E and OC 43. Am Rev Respir Dis. 1972; 105(5):805-11.

25. Tyrrell DA, Cohen S, Schlarb JE. Signs and symptoms in common colds. Epidemiol Infect. 1993;111(1):143-56.

26. Abdul-Rasool S, Fielding BC. Understanding human coronavirus HCoV-NL63. Open Virol J. 2010;4:76-84.

27. Mclntosh K, Becker WB, Chanock RM. Growth in suckling-mouse brain of "IBV-like" viruses from patients with upper respiratory tract disease. Proc Natl Acad Sci U S A. 1967;58(6):2268-73.

28. Woo PC, Lau SK, Chu CM, Chan KH, Tsoi HW, Huang Y, et al. Characterization and complete genome sequence of a novel coronavirus, coronavirus HKU1, from patients with pneumonia. J Virol. 2005;79(2):884-95.

29. Vabret A, Mourez T, Gouarin S, Petitjean J, Freymuth F. An outbreak of coronavirus OC43 respiratory infection in Normandy, France. Clin Infect Dis. 2003;36(8):985-9.

30. Esper F, Ou Z, Huang YT. Human coronaviruses are uncommon in patients with gastrointestinal illness. J Clin Virol. 2010;48(2):131-3.

31. Vabret A, Dina J, Gouarin S, Petitjean J, Tripey V, Brouard J, et al. Human (non-severe acute respiratory syndrome) coronavirus infections in hospitalised children in France. J Paediatr Child Health. 2008;44(4):176-81.

32. Peiris JS, Yuen KY, Osterhaus AD, Stöhr K. The severe acute respiratory syndrome. N Engl J Med. 2003;349(25):2431-41.

33. Peiris JS, Chu CM, Cheng VC, Chan KS, Hung IF, Poon LL, et al. Clinical progression and viral load in a community outbreak of coronavirusassociated SARS pneumonia: a prospective study. Lancet. 2003;361(9371): $1767-72$.

34. Leung WK, To KF, Chan PK, Chan HL, Wu AK, Lee N, et al. Enteric involvement of severe acute respiratory syndrome-associated coronavirus infection. Gastroenterology. 2003;125(4):1011-7.

35. Chan KH, Poon LL, Cheng VC, Guan Y, Hung IF, Kong J, et al. Detection of SARS coronavirus in patients with suspected SARS. Emerg Infect Dis. 2004; 10(2):294-9.

36. Arabi YM, Harthi A, Hussein J, Bouchama A, Johani S, Hajeer AH, et al. Severe neurologic syndrome associated with Middle East respiratory syndrome corona virus (MERS-CoV). Infection. 2015;43(4):495-501.

37. Assiri A, Al-Tawfiq JA, Al-Rabeeah AA, Al-Rabiah FA, Al-Hajjar S, Al-Barrak A, et al. Epidemiological, demographic, and clinical characteristics of 47 cases of Middle East respiratory syndrome coronavirus disease from Saudi Arabia: a descriptive study. Lancet Infect Dis. 2013;13(9):752-61.

38. Corman VM, Albarrak AM, Omrani AS, Albarrak MM, Farah ME, Almasri M, et al. Viral shedding and antibody response in 37 patients with Middle East respiratory syndrome coronavirus infection. Clin Infect Dis. 2016;62(4):47783.

39. Lu R, Zhao X, Li J, Niu P, Yang B, Wu H, et al. Genomic characterisation and epidemiology of 2019 novel coronavirus: implications for virus origins and receptor binding. Lancet. 2020;395(10224):565-74.

40. Huang C, Wang Y, Li X, Ren L, Zhao J, Hu Y, et al. Clinical features of patients infected with 2019 novel coronavirus in Wuhan, China. Lancet Lancet. 2020;395(10223):497-506.

41. Chen N, Zhou M, Dong X, Qu J, Gong F, Han Y, et al. Epidemiological and clinical characteristics of 99 cases of 2019 novel coronavirus pneumonia in Wuhan, China: a descriptive study. Lancet. 2020;395(10223):507-13.

42. Fang D, Ma JD, Guan JL, Wang MR, Song Y, Tian DA, et al. Manifestations of digestive system of hospitalized patients with coronavirus disease 2019 in Wuhan, China: a single-center descriptive study. Chin J Dig. 2020;40(3):1516.

43. Zhang $H$, Kang Z, Gong H, Xu D, Wang J, Li Z, et al. Digestive system is a potential route of COVID-19: an analysis of single-cell coexpression pattern of key proteins in viral entry process. Gut. 2020;69(6):1010-8.

44. Holshue ML, DeBolt C, Lindquist S, Lofy KH, Wiesman J, Bruce H, et al. First case of 2019 novel coronavirus in the United States. N Engl J Med. 2020 382(10):929-36.
45. Liu Q, Wang RS, Qu GQ, Wang YY, Liu P, Zhu YZ, et al. Gross examination report of a COVID-19 death autopsy. J Forensic Med. 2020;36(1):21-3.

46. Yang ZW, Li GW, Dai XL, Liu GR, Li G, Jie YS. Three cases of novel coronavirus pneumonia with viral nucleic acids still positive in stool after throat swab detection turned negative. Chin J Dig. 2020;40(02):77-9.

\section{Ready to submit your research? Choose BMC and benefit from:}

- fast, convenient online submission

- thorough peer review by experienced researchers in your field

- rapid publication on acceptance

- support for research data, including large and complex data types

- gold Open Access which fosters wider collaboration and increased citations

- maximum visibility for your research: over $100 \mathrm{M}$ website views per year

At BMC, research is always in progress.

Learn more biomedcentral.com/submissions 